\title{
A STUDY ON KNOWLEDGE TOWARDS BRAIN DEATH AMONG RESIDENTS IN INDONESIA
}

\author{
Asra Al Fauzi ${ }^{1}$, Christrijogo Sumartono Waloejo ${ }^{2}$, Abdulloh Machin ${ }^{3}$, Muhammad Ja'far Shodiq ${ }^{4}$ \\ ${ }^{1}$ Department of Neurosurgery, ${ }^{2}$ Department of Anesthesiology and Reanimation, ${ }^{3}$ Department of Neurology, \\ Faculty of Medicine, Universitas Airlangga, Dr. Soetomo Academic Medical Center Hospital, ${ }^{4}$ Medical School, \\ Faculty of Medicine, Universitas Airlangga, Surabaya, Indonesia
}

\section{ABSTRACT}

\begin{abstract}
This research was conducted to evaluate the knowledge and diagnosis of brain death among resident in Indonesia. This study used an observational analytic study with a cross-sectional study design using a questionnaire. The research subjects consisted of 132 level 2 (after 2 years of residency) and level 3 (after 4 years of residency) residents, the total sampling for which was taken from the departments of Neurosurgery, Anesthesiology, and Neurology at Dr. Soetomo Academic Medical Center Hospital, Surabaya, Indonesia. Data were taken from November 2018 to January 2019. A total of 132 residents of Neurosurgery, Neurology, and Anesthesiology participated in this study. From the series of studies, residents' knowledge of the concept of brain death was in the sufficient category (41.7\%), residents' knowledge of the technical diagnosis of brain death was in the good category (40.2\%), residents' knowledge of brain death examination was in the less category (43.2\%), and finally, it was found that the resident's knowledge of brain death was in a good category (35.6\%). There were also significant differences in knowledge of brain death between Neurosurgery, Neurology, and Anesthesiologist Resident $(P<0.001)$ and knowledge of brain death between level 2 and level 3 residents $(P=0.032)$. In general, the Indonesian resident doctors' knowledge of brain death is adequate, but knowledge of the clinical examination of brain death is still lacking. Further research must be carried out to promote knowledge of brain death in residents as well as professional doctors/specialists, so that the number of organ transplants, especially in Indonesia, will increase.
\end{abstract}

Keywords: Brain death; knowledge; resident doctor; Indonesia

\section{ABSTRAK}

Penelitian ini dilakukan untuk mengevalusi pengetahuan mati otak pada dokter PPDS I di indonesia dan mengevaluasi cara mendiagnosis mati otak di Indonesia.Data dikumpulkan dengan menggunakan kuesioner yang terdiri dari 21 item pertanyaan. Sebanyak 132 dokter PPDS I Bedah Saraf, Neurologi, dan Anestesiologi berpartisipasi dalam penelitian ini. Data diambil selama November 2018 sampai Januari 2019. Didapatkan pengetahuan mati otak pada dokter PPDS I paling banyak pada kategori baik (35,6\%), pengetahuan dokter PPDS I terhadap konsep mati otak paling banyak pada kategori cukup (41,7\%), pengetahuan dokter PPDS I terhadap teknis mendiagnosis mati otak paling banyak pada kategori baik (40,2\%), dan pengetahuan dokter PPDS I terhadap pemeriksaan mati otak paling banyak pada kategori kurang (43,2\%). Didapatkan pula perbedaan yang signifikan terhadap pengetahuan mati otak antara dokter PPDS I Bedah Saraf, Neurologi, dan Anestesiologi $(P<0.001)$ dan pengetahuan mati otak antara dokter PPDS I tingkat 2 dan 3 (P=0,032). Pengetahuan dokter PPDS I di Indonesia terhadap mati otak sudah cukup baik namun masih kurangnya pengetahuan terhadap pemeriksaan mati otak pada dokter PPDS I tersebut. Penelitian lebih lanjut harus dilakukan untuk mempromosikan pengetahuan terhadap kematian otak pada dokter PPDS I maupun pada dokter profesional/spesialis agar angka transplantasi organ utamanya di Indonesia menjadi meningkat.

Kata kunci: Kematian otak; pengetahuan; dokter residen; Indonesia

Correspondence: Asra Al Fauzi, Department of Neurosurgery, Faculty of Medicine, Universitas Airlangga, Dr. Soetomo Academic Medical Center Hospital, Jalan Prof. Dr. Moestopo 6-8, Surabaya 60286, Indonesia. Phone : +6281-333934999. Fax : +6231-5025188. E-mail : asra-a-f-11@ pasca.unair.ac.id

pISSN:2355-8393 • eISSN: 2599-056x • doi: http://dx.doi.org/10.20473/fmi.v56i2.21235

- Fol Med Indones. 2020;56:140-147 • Received 14 Oct 2019 • Accepted 16 Apr 2019

- Open access under CC-BY-NC-SA license • Available at https://e-journal.unair.ac.id/FMI/

\section{INTRODUCTION}

The criteria for diagnosing death continue to develop from century to century. These criteria along with technological advancements have helped humans diagnose death. Somatic criteria, such as the presence of decomposition and rigor mortis, are the oldest criteria for diagnosing death in human history. Then, in 1963, 
the Belgian surgeon, Guy Alexandre, used neurological criteria or brain death in diagnosing death, which later triggered the first transplant from a heart donor. Since that time, the criteria for death have been based on brain death (Gardiner et al 2012). Brain death is a condition in which the brain irreversibly loses its function. Brain death is characterized by loss of brain stem reflexes, loss of motor response, loss of breath function in normothermic conditions, and coma in patients with lesions in the brain that are irreversible and without metabolic disorders or the influence of drugs (Wijdicks 2002).

Brain death consists of three important signs, coma, an absence of brain stem reflexes, and apnea (Goila \& Pawar 2009). By Ministry of Health Regulation in Indonesia (2014), brain death is characterized by the absence of brain stem reflexes and breathing (Kementrian Kesehatan Republik Indonesia 2014). Brain death is caused by many factors, including head trauma due to motor vehicle accidents, frequent accidents, falls from heights, gunshot wounds, bleeding in the brain due to aneurysms and strokes, drug overdose, drowning, poisoning, and other causes (National Kidney Foundation 2014).

In diagnosing brain death, there are differences in criteria in various countries of the world. Not all of these criteria can be universally accepted, so understanding about brain death is very important, so as not to cause confusion and the possibility of ethical problems (Sheerani et al 2008). After brain death can be diagnosed, organs in patients can be used for organ transplants. Although the development of organ transplants in the medical world is growing significantly, the number of patients waiting for transplants is far more than the number of donors day by day around the world (Kumar 2016, Kocaay et al 2015). Indonesia, as a country with a majority Muslim population, has not experienced significant development in organ transplants. For example, in kidney transplantation, the number is still less than $3 \%$ applied to patients with kidney failure (Mochtar et al 2017). In Islam, there is a view that life is integration between body, soul, and spirit, not just on a certain object such as the brain. In addition, culturally, in eastern countries like Indonesia, there is also a view that states that death must occur naturally, no one can determine (Yang \& Miller 2015). In Indonesia, brain death examinations are regulated by the Ministry of Health Regulation of 2014. In its determination, the diagnosis of brain death is carried out by a team of doctors of three doctors, which are composed of an anesthetist, a neurologist, and one member from other, related specialties.
A doctor's knowledge of brain death is very important so that the diagnosis is correct and accurate, so as not to raise ethical problems. With a good understanding of brain death knowledge, it is also expected that the number of organ transplants will increase, especially in Indonesia. However, until now, there has been no research on the knowledge of brain death among doctors in Indonesia, which, incidentally, is a country with the largest Muslim majority in the world. Therefore, researchers identified a need to examine this to find out the knowledge of brain death among Indonesian residents.

\section{MATERIALS AND METHODS}

This study used an observational analytic study with a cross-sectional study design using a questionnaire. The research subjects consisted of 132 level 2 (after 2 years of residency) and level 3 (after 4 years of residency) residents, the total sampling for which was taken from the departments of Neurosurgery, Anesthesiology, and Neurology at Dr. Soetomo Academic Medical Center Hospital, Surabaya, Indonesia. Researchers chose the research subjects from the three departments because in Indonesia, neurologists, anesthesiologists, and one other doctor, who is usually a neuropediatrician or neurosurgeon, are responsible for diagnosing brain death.

Researchers also chose levels 2 and 3 residents because the researchers considered they had gained a lot of experience in dealing with brain death in the intensive care unit (ICU). This study uses a self-created questionnaire based on the Local Regulation and previous research (Magalhães et al 2016, Wijdicks 2003). The questions in this questionnaire have passed two validations. The final questionnaire consisted of 18 questions about brain death, consisting of four questions about the concept of brain death, three questions about the technical diagnosis of brain death, and 11 questions about clinical examination on brain death. This questionnaire also added three additional questions about ancillary testing, actions after the patient was diagnosed with brain death, and knowledge of the regulations for determining death and utilizing donor organs in Indonesia to complete the data. Questions about brain death are multiple-choice questions that can be answered A, B, C, D, or E. The correct answer is coded 1 and the wrong answer is coded 0 . After that, the number of item scores is added to calculate the total score of brain death knowledge, and also the total score of the brain death concept knowledge, total score of technical knowledge of diagnosing brain death, and total score of brain death examination knowledge. 
Subsequently, the score will be categorized as good, sufficient, or lacking. Knowledge is categorized as good when $75-100 \%$ of the questions are answered correctly, sufficient if $55-75 \%$ are answered correctly, and less if $<50 \%$ are answered correctly. Additional questions on this questionnaire are in the form of two multiple choice questions that can be answered A, B, C, D, or E and one question "know or do not know." Right and know answers are coded 1 and wrong answers and do not know are coded 0. Each question is addressed in the discussion. The researcher met with each of the research subjects individually from November 2018 to January 2019 at Dr. Soetomo Academic Medical Center Hospital Surabaya. Each resident answered questions for 20 minutes directly by "face-to-face interview" with the researcher. After all the survey data were collected, the data were analyzed using IBM SPSS Statistics 25. Data analysis includes descriptive statistics, validation tests using the Pearson Product-Moment Correlation method, the Mann-Whitney test, and the Kruskal-Wallis test. This study was approved by the ethics committee of Dr. Soetomo Academic Medical Center Hospital Surabaya.

\section{RESULTS}

\section{Demographic characteristics of subjects}

The study followed 132 residents, of whom 21 (15.9\%) are neurosurgery residents, $39(29.5 \%)$ are neurology residents and $72(54.5 \%)$ are anesthesiology residents. There were 65 level 3 residents $(49.2 \%)$ and 67 level 2 residents $(50.8 \%)$. Most of the residents $(94,71.2 \%)$ were male, while $38(28.8 \%)$ were women. Some residents were $=30$ years old $(50 \%)$ and some were $>30$ years old $(50 \%)$
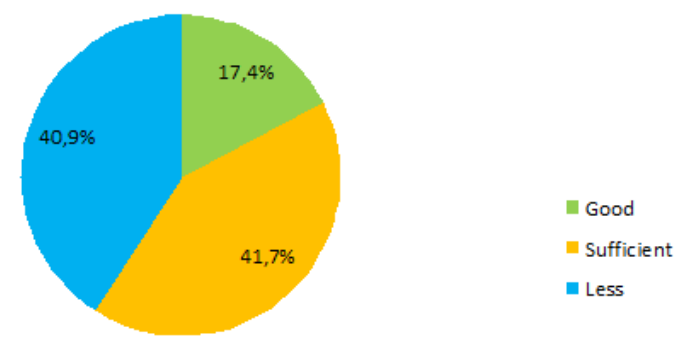

Fig. 1. Distribution of knowledge of the concept of brain death.

In this study, 55 residents (41.7\%) had knowledge of the concept of brain death in the sufficient category, with 54 $(40.9 \%)$ in the less category and $23(17.4 \%)$ in the good category.
In this study, 53 residents $(40.2 \%)$ had knowledge of the technical diagnosis of brain death in the good category, with $41(31.1 \%)$ in the sufficient category and 38 $(28.8 \%)$ in the less category.

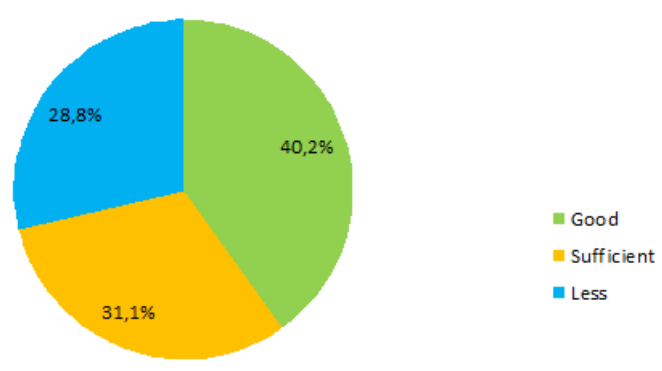

Fig. 2. Distribution of technical knowledge in diagnosing brain death.

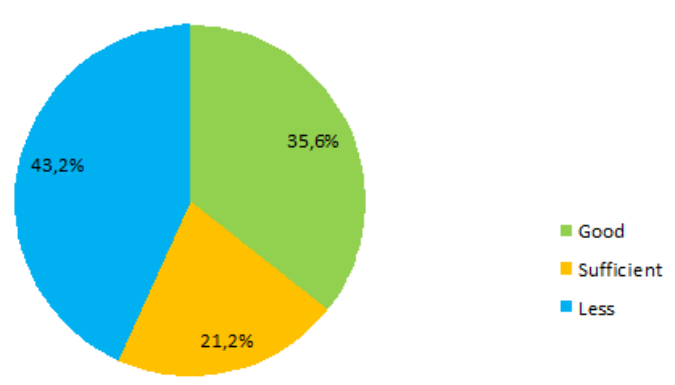

Fig. 3. Distribution knowledge of brain death clinical examination.

In this study, 57 residents (43.2\%) had knowledge of the examination of brain death in the poor category, with 47 $(35.6 \%)$ in the good category and $28(21.2 \%)$ in the sufficient category.

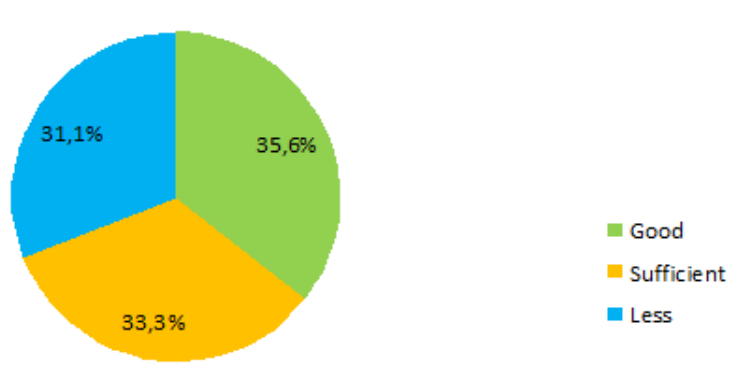

Fig. 4. Distribution of brain death knowledge.

In this study, 47 residents (35.6\%) had overall knowledge of brain death in the good category, with 44 $(33.3 \%)$ in the sufficient category and $41(31.1 \%)$ in the less category. 
Table 1. Distribution of knowledge of ancillary test for brain death

\begin{tabular}{lcc}
\hline Ancillary test to confirm brain death & Total & Percentage \\
\hline Correct & 129 & $97.7 \%$ \\
Incorrect & 3 & $2.3 \%$ \\
\hline Total & 132 & $100 \%$ \\
\hline
\end{tabular}

Table 2. Distribution of selection of actions after patients have been diagnosed with brain death

\begin{tabular}{|c|c|c|}
\hline $\begin{array}{l}\text { Actions after patients have been diagnosed } \\
\text { with brain death }\end{array}$ & Total & Percentage \\
\hline Correct & 108 & $81.8 \%$ \\
\hline Incorrect & 24 & $18.2 \%$ \\
\hline Total & 132 & $100 \%$ \\
\hline
\end{tabular}

Table 3. Distribution of knowledge of regulations determining deaths and utilizing donor organs in Indonesia

\begin{tabular}{lcc}
\hline $\begin{array}{l}\text { Knowledge of regulations determining deaths and } \\
\text { utilizing donor organs in Indonesia }\end{array}$ & Total & Percentage \\
\hline Know & 50 & $37.9 \%$ \\
Do not know & 82 & $62.1 \%$ \\
\hline Total & 132 & $100 \%$ \\
\hline
\end{tabular}

Table 4. Knowledge differences in brain death based on characteristics of research subjects

\begin{tabular}{|c|c|c|c|c|c|}
\hline Subjects' Characteristics & Total $(\%)$ & Good (\%) & Sufficient $(\%)$ & Less (\%) & $\mathrm{P}$ value \\
\hline Department & & & & & $<0.001$ \\
\hline Neurosurgery ${ }^{\mathrm{a}}$ & $21(15.9)$ & $3(14.29)$ & $2(9.52)$ & $16(76.19)$ & \\
\hline Neurology ${ }^{\mathrm{b}}$ & $39(29.5)$ & $17(43.59)$ & $19(48.72)$ & $3(7.69)$ & \\
\hline Anesthesiology $y^{b}$ & $72(54.5)$ & $27(37.50)$ & $23(31.94)$ & $22(30.56)$ & \\
\hline Level of Resident & & & & & 0.032 \\
\hline Level $3^{\mathrm{a}}$ & $65(49.2)$ & $29(44.62)$ & $20(30.77)$ & $16(24.61)$ & \\
\hline Level $2^{b}$ & $67(50.8)$ & $18(26.87)$ & $24(35.82)$ & $25(37.31)$ & \\
\hline Gender & & & & & 0.223 \\
\hline Male $^{\mathrm{a}}$ & $94(71.2)$ & $32(34.04)$ & $29(30.85)$ & $33(35.11)$ & \\
\hline Female $^{\mathrm{a}}$ & $38(28.8)$ & $15(39.47)$ & $15(39.47)$ & $8(21.06)$ & \\
\hline Age & & & & & 0.832 \\
\hline$\leq 30$ years $^{\mathrm{a}}$ & $66(50)$ & $23(34.85)$ & $22(33.33)$ & $21(31.82)$ & \\
\hline$>30$ years $^{\mathrm{a}}$ & $66(50)$ & $24(36.37)$ & $22(33.33)$ & $20(30.30)$ & \\
\hline
\end{tabular}

In this study, 129 residents $(97.7 \%)$ were correct in choosing to use ancillary test (Electroencephalogram) to confirm brain death in patients, and three residents $(2.3 \%)$ were wrong in choosing one. Meanwhile, 108 residents $(81.8 \%)$ were correct in choosing the action taken after the patient was diagnosed with brain death, and $24(18.2 \%)$ were wrong in choosing the action taken after the patient was diagnosed with brain death. Furthermore, 50 residents $(37.9 \%)$ knew about the Ministry of Health Regulation of 2014, which contained the determination of death and utilization of donor organs in Indonesia, while 82 residents $(62.1 \%)$ did not know.
The results of the questionnaire data were then analyzed for different brain death knowledge with non-parametric analysis using the Kruskal-Wallis test on departmental demographics and the Mann-Whitney $U$ test on resident level, gender, and age demographics. The test results are presented in the following table.

Based on the results of the different tests above, a Pvalue of $<0.001$ (P-value $<0.05)$ was obtained in department demographics, which meant there were significant differences in knowledge of brain death in Neurosurgery, Neurology, and Anesthesiology residents. Among these three departments, there were 
significant differences in brain death knowledge between Neurosurgery and Neurology residents ( $P$ $<0.001)$ and between Neurosurgery and Anesthesiology residents $(\mathrm{P}=0.001)$. However, there was no significant difference in brain death knowledge between residents of Neurology and Anesthesiology $(\mathrm{P}=0.085)$. Also, resident-level demographics obtained a $\mathrm{P}$ value of 0.032 ( $\mathrm{P}$ value $<0.05)$, which means that there are significant differences in brain death knowledge between level 3 and 2 residents. There is also a $\mathrm{P}$ value of $0.223(\mathrm{P}-$ value $>0.05$ ) in the gender category, which means that there is no significant difference in brain death knowledge between male and female residents. Also, a $\mathrm{P}$ value of 0.832 ( $\mathrm{P}$ value $>0.05$ ) was obtained in the age category, which means there is no significant difference in brain death knowledge for residents aged $=30$ years and $>30$ years.

\section{DISCUSSION}

In Indonesia, organ transplantation has not experienced significant development. For example, in kidney transplantation, the number is still less than 3\% applied to patients with kidney failure (Mochtar et al 2017). The religious and cultural aspect is one of the factors that greatly influence the Indonesian people as concerns organ transplants. Indonesia is the country with the largest number of Muslims in the world, which is $207,176,162$ people or around $87 \%$ of the population (Badan Pusat Statistik 2010). In Indonesia, organ transplants from living donors are still low, while those of brain death patients are much lower. This is different from Turkey, Saudi Arabia, Iran, and Malaysia, where organ transplants are more often done (Ghods 2015, Bennett \& Hany 2009). Most of these countries have imposed regulations on determining brain death for a long time, whereas in Indonesia, clear regulations have only been issued in 2014 .

Determination of death in Indonesia is regulated by the Ministry of Health Regulation of 2014. Determination of a person's death can be done using the criteria of clinical/conventional death diagnosis or by brain death criteria. The criteria for diagnosing clinical/conventional death are based on the permanent cessation of the functioning of the cardio-circulatory system and respiratory system, while the criteria for diagnosing brain death are based on irreversible loss of brain function (Kementrian Kesehatan Republik Indonesia 2014). In this study, the largest percentage (35.6\%) of residents had good knowledge of brain death. However, the amount does not differ greatly between good, sufficient, and less knowledge. Thirty-three-point three percent of residents had less knowledge and $31.1 \%$ of residents had sufficient knowledge of brain death. In the additional question on the questionnaire, most (62.1\%) residents did not know about the local regulation concerning the determination of death and utilization of donor organs, which became the basic guideline for making questionnaires in this study. Because most residents did not know about the regulation, this caused a variety of resident knowledge concerning brain death. This result is not much different from the research conducted by Jeon (2012) in Korea; in that study, the knowledge of professional medical personnel on brain death and organ donors was still not developed, in addition, passivity from medical personnel in handling brain death and organ harvesting was also found (Jeon et al 2012). Likewise, in Pakistan, in a study conducted by Sheerani (2008), it was found that there was still confusion and a lack of understanding of brain death, especially among junior doctors (Sheerani et al 2008).

Brain death is death that is based on irreversible cessation of all brain functions, including the brain stem (WHO 2012). In this study, a majority of the residents (41.7\%) had sufficient knowledge of the concept of brain death. However, the amount does not differ greatly between good, sufficient, and less knowledge. As many as $40.9 \%$ of residents have less knowledge and only $17.4 \%$ of residents have sufficient knowledge of brain death. This result is similar to the research in Teresina, Brazil, conducted by Magalhães (2016), where found that most $(85.6 \%)$ of the medical staff knew about the concept of brain death (Magalhães et al 2016).

Examination of brain death in Indonesia can only be done by a team of three doctors. Team members consist of an anesthesiologist, a neurologist, and one other doctor. In the case of determining brain death performed on prospective organ donors, the team of doctors cannot include a doctor involved in the act of transplantation. Each team member conducts an independent and separate examination, and a diagnosis of brain death must also be delivered in the ICU (Kementrian Kesehatan Republik Indonesia 2014). In this study, the component of knowledge was incorporated into the knowledge of technically diagnosing brain death. According to the results, as many as $40.2 \%$ of residents have good knowledge, $31.1 \%$ have sufficient knowledge, and $28.8 \%$ have less knowledge. This result is better than the Indian study conducted by Mohod (2017), which found that only $12.64 \%$ of residents knew about the number of doctors and doctors who were entitled to conduct brain death examinations in India (Mohod et al 2017).

Examination of the brain stem reflex and the apnea test is used in the examination of brain death in Indonesia. Examination of the brain stem reflex consists of the 
pupillary reflex, corneal reflex, oculocephalic reflex, vestibulo-ocular reflex, and gag reflex. The apnea test is carried out by pre-oxidizing with $\mathrm{O} 2100 \%$ for 10 minutes, then ensuring the initial $\mathrm{pCO} 2$ testing is within the range of $40-60 \mathrm{mmHg}$. After that, tracheal insufflation with $\mathrm{O} 2100 \%, 6 \mathrm{~L} / \mathrm{min}$ is administered and the patient is observed for 10 minutes. If the brain stem areflexia test and apnea test are positive, then the test must be repeated once again within an interval of 25 minutes to 24 hours (Kementrian Kesehatan Republik Indonesia 2014). In this study, it was found that most (43.2\%) residents had less knowledge of examining for brain death. However, as many as $35.6 \%$ of residents have good knowledge and $21.2 \%$ of residents have sufficient knowledge.

Examination of brain death in Indonesia is based on the brain stem reflex test and apnea tests only. In this study, the majority of residents $(97.7 \%)$ knew what modalities should be used to support brain death. In another study in Teresina, Brazil conducted by Magalhães (2016), it was also found that $94.4 \%$ of medical staff knew about supporting tests for the diagnosis of brain death (Magalhães et al 2016). Even though in Indonesia the ancillary tests are not regulated in law, these tests are in some countries of Europe, Central and South America, and Asia (Wijdicks 2002). These ancillary tests are very helpful for doctors in diagnosing brain death, especially when there is uncertainty in the neurological examination of brain stem reflexes. But in its use, doctors must be correct in choosing and considering the use of these ancillary tests to support the diagnosis of brain death (Welschehold et al 2012).

Determination of the time of death of a patient in Indonesia is at the time of brain death as declared by the doctors, not when the ventilator is removed from the patient or the heart stops beating. After a patient is declared to have experienced brain death, then all life support therapy must be stopped immediately with the consent of the patient's family or the representative. However, if the patient is an organ donor, then life support therapy must continue until the required organ is taken (Kementrian Kesehatan Republik Indonesia 2014). In this study, $81.8 \%$ of residents will immediately stop life support therapy in patients who have been diagnosed with brain death with family approval or representation. However, there are still some residents who claim that they will continue to provide life support therapy until the heart stops beating. This shows that there is still confusion among residents in stopping or continuing life support therapy in patients who have been diagnosed with brain death.

In this study, we found significant differences in knowledge in diagnosing brain death among residents of
Neurosurgery, Neurology, and Anesthesiology departments $(\mathrm{p}<0.001)$. Among these three departments, there was a significant difference in brain death knowledge between Neurosurgery and Neurology residents $(\mathrm{P}<0.001)$ and between Neurosurgery and Anesthesiology residents $(\mathrm{P}=0.001)$. However, there was no significant difference in brain death knowledge between the Neurology and Anesthesiology residents $(\mathrm{P}=0.085)$. Among the three departments, the best knowledge was obtained by Neurology residents with a good category of $43.59 \%$, a sufficient category of $48.72 \%$, and a less category of $7.69 \%$. This was followed by Anesthesiology residents with a good category of $37.50 \%$, a sufficient category of $31.94 \%$, and a less category of $30.56 \%$, while Neurosurgery residents obtained a good category of $14.29 \%$, a sufficient category of $9.52 \%$, and a less category of $76.19 \%$. In Indonesia, the determination of brain death is carried out by a neurologist, an anesthesiologist, and one other doctor, so that the competence to diagnose brain death is more emphasized for neurologists and anesthesiologists (Konsil Kedokteran Indonesia 2012). In general, however, in Indonesia, there are no special competencies that are taught during the residency to conduct structured brain death examinations.

In this study, there were also significant differences in knowledge in diagnosing brain death between level 2 and 3 residents $(\mathrm{P}=0.032)$. The best knowledge was obtained by level 3 residents with a good category of $44.62 \%$, a sufficient category of $30.77 \%$, and a less category of $24.61 \%$. This was followed by level 2 residents with a good category of $26.87 \%$, a sufficient category of $35.82 \%$, and a less category of $37.31 \%$. According to Mubarak (2011), education and experience are topics that affect each person's knowledge. A resident level 3 has more clinical experience than a level 2, so there is a significant difference in knowledge in diagnosing brain death. This is in line with research conducted by Jeon (2012) in Korea, whose study found differences in brain death knowledge that were significant in the education level category in medical personnel (Jeon et al 2012).

According to Mubarak (2011), age is also something that affects one's knowledge. Changes in the psychology or mental aspects of a person according to age will, it is hoped, cause a person's level of thinking to become more mature (Mubarak 2011). However, in this study, there were no significant differences between residents aged $=30$ years and $>30$ years $(\mathrm{P}=0.223)$. This is in line with research conducted by Jeon (2012) in Korea, which found no significant difference in brain death knowledge according to the age category among medical personnel (Jeon et al 2012). 
In this study, there was also no significant difference in knowledge in diagnosing brain death between male and female residents $(\mathrm{P}=0.832)$. According to Mubarak (2011), factors that influence knowledge include education, employment, age, interests, experience, cultural environment, and information. Gender does not include factors that influence the knowledge of a person (Mubarak 2011). The results of this study are in line with a study conducted by Jeon (2012) in Korea, which found no significant differences in brain death knowledge in male and female medical personnel (Jeon et al 2012).

This research is very important because it is the first one done on the topic in Indonesia. This study also used primary data with questionnaires to Neurosurgery, Neurology, and Anesthesiology residents who were doctors in charge of diagnosing brain death in Indonesia. However, this study is limited to resident research subjects only, and does not involve other health workers like a nurse and specialist doctor. This study examined the knowledge of brain death only, and did not examine aspects of attitude and behavior. This study is expected to evaluate residents' ability in diagnosing brain death, which is expected to raise awareness for organ transplantation in Indonesia.

\section{CONCLUSION}

Based on the results of research on brain death knowledge in Indonesian residents, it can be concluded that residents' knowledge of brain death in Indonesia is good enough; however, knowledge of brain death clinical examination among residents still needs to be improved. There were significant differences in the knowledge of brain death among residents of Neurosurgery, Neurology, and Anesthesiology Departments. Knowledge about brain death in residents needs to be increased to a higher level, especially those who work in neurointensive care. Further research on aspects of residents and other health workers' attitudes and behavior in brain death determination is needed in the future.

\section{ACKNOWLEDGMENTS}

We thank the participants for their time and interest in taking part of this study.

\section{CONFLICT OF INTEREST}

The study was designed and conducted independently by the research team. The authors declare no financial or other conflicts of interest. All authors certify that they have no affiliations with or involvement in any organization or entity with any financial interest (such as honoraria; educational grants; participation in speakers' bureaus; membership, employment, consultancies, stock ownership, or other equity interest; and expert testimony or patent-licensing arrangements), or non-financial interest (such as personal or professional relationships, affiliations, knowledge or beliefs) in the subject matter or materials discussed in this manuscript.

\section{FUNDING}

The study was funded independently by the research team.

\section{REFERENCES}

Badan Pusat Statistik (2010). Penduduk menurut wilayah dan agama yang dianut

Bennett PN, Hany A (2009). Barriers to kidney transplants in Indonesia?: a literature review, 41-49

Gardiner D, Shemie S, Manara A, Opdam H (2012). International perspective on the diagnosis of death. $\mathrm{Br}$ J Anaesth 108, i14-i28

Ghods AJ (2015). Current status of organ transplant in Islamic countries. DOI:10.6002/ect.mesot2014.017

Goila A, Pawar M (2009). The diagnosis of brain death. Indian J Crit Care Med 13, 7

Jeon KO, Kim BN, Kim HS, et al (2012). A study on knowledge and attitude toward brain death and organ retrieval among health care professionals in Korea. Transplant Proc 44, 859-861

Kementrian Kesehatan Republik Indonesia (2014). Permenkes Republik Indonesia Nomor 37 Tahun 2014 tentang Penentuan Kematian Dan Pemanfaatan Organ Donor

Kocaay AF, Celik SU, Eker T, Oksuz NE, Akyol C, Tuzuner A (2015). Brain death and organ donation: knowledge, awareness, and attitudes of medical, law, divinity, nursing, and communication students. Transplant Proc 47, 1244-1248

Konsil Kedokteran Indonesia (2012). Standar kompetensi dokter spesialis anestesiologi dan terapi intesif, 1-44

Konsil Kedokteran Indonesia (2012). Standar kompetensi dokter spesialis anestesiologi dan terapi intesif, 1-90

Kumar L (2016). Brain death and care of the organ donor. J Anaesthesiol Clin Pharmacol 32, 146-152

Magalhães JV, Veras KN, Maria C, Mendes DM (2016). Evaluation of the knowledge of intensive care doctors in Teresina concerning brain death Research articles. 24, 156-164 
Mochtar CA, Alfarissi F, Soeroto AA, et al (2017). Milestones of kidney transplantation in Indonesia, 229-236.

Mohod V, Kondwilkar B, Jadoun R (2017). An institutional study of awareness of brain - death declaration among resident doctors for cadaver organ donation, 17-23. DOI:10.4103/ija.IJA

Mubarak W (2011). Promosi kesehatan untuk kebidanan. Jakarta Salemba Medika

National Kidney Foundation (2014). Brain Death

Sheerani M, Urfy MZS, Khealani B, Patel J, Qamarunnisa, Rath S (2008). Brain death: Concepts and knowledge amongst health professionals in province of Sindh, Pakistan. J Pak Med Assoc 58, 352-356
Welschehold S, Boor S, Reuland K, et al (2012). Technical aids in the diagnosis of brain death 109 , 624-631. DOI:10.3238/arztebl.2012.0624

WHO (2012). International guidelines for the determination of death - Phase 1

Wijdicks EFM (2002). Brain death worldwide: Accepted fact but no global consensus in diagnostic criteria. Neurology 20-25. DOI:10.1212/WNL.58.1.20

Wijdicks EFM (2003). The neurologist and Harvard criteria for brain death. Neurology 61, 970-976

Yang Q, Miller G (2015). East-west differences in perception of brain death: review of history, current understandings, and directions for future research. J Bioeth Inq. DOI:10.1007/s11673-014-9564-X 